\title{
A FOGALMI VÁLTÁS ELMÉLETEI
}

\section{KOROM ERZSÉBET}

József Attila Tudományegyetem, Pedagógiai Tanszék, Szeged

E-mail: korom@edpsy.u.szeged.hu

\begin{abstract}
A pedagógiai és a pszichológiai kutatások egyik érdekes találkozási pontja az 1980-as évek elején kibontakozó, a fogalmak tanulásával, az ismeretelsajátítás folyamataival foglalkozó, a szakirodalomban „fogalmi váltás”-ként (conceptual change) ismert kutatási irány. E kutatási területen összefonódnak az oktatás gyakorlatával, elsősorban a természettudományok tanításával foglalkozó vizsgálatok és a kognitív fejlödéslélektani megközelitések. Mindkét irány kiindulópontja az a tanulásszemlélet, amely a tanulás aktív jellegét hangsúlyozza. A tanuló az elözetes ismeretei alapján értelmezi az új információt, konstruálja meg tudását. A fogalmi váltás kutatások oktatáshoz szorosabban kötődő ága a tanulást értelmezi fogalmi váltásként, amely során azokat a tanulói fogalmakat, amelyek nem felelnek meg a tudományos nézeteknek, le kell cserélni a tudományos fogalmakra. A kognitív fejlödéspszichológiában gyökerezö fogalmi váltás vizsgálatok viszont arra keresik a választ, hogy mi történik a régi és az új ismeretek kölcsönhatásakor, milyen változások, váltások mennek végbe a fogalmi rendszerben, és hogyan lehet elösegíteni az új információk megértését. E tanulmány célja, hogy (1) áttekintse a fogalmi váltás kutatások két évtizedének legfontosabb tendenciáit; (2) bemutassa a legjelentösebb empirikus munkákat és a belólük kiinduló elméleteket;(3) felhívja a figyelmet a még meguálaszolandó kérdésekre; és (4) érzékeltesse a fogalmi váltás kutatások lehetséges jövöbeni irányait. E kutatási terület eredményei számos információval szolgálnak a tanulók fogalmi fejlödésének megértéséhez, továbbá felhívják a figyelmet néhány pedagógiai következményre is. Kiemelik azt, hogy az oktatás során az eddigieknél sokkal nagyobb figyelmet kell fordítani a tanulók elözetes ismereteire, meggyözödéseire, naiv elméleteire, valamint a tudatos fogalomtanitásra és fogalomtanulásra.
\end{abstract}

Kulcsszavak: ismeretelsajátítás, fogalomtanulás, fogalmi váltás, tévképzet, fogalomtanitás, természettudományos nevelés, kognitív fejlödéslélektan

A fogalmi váltás (conceptual change) kifejezés az 1980-as évek elején jelent meg a pedagógiai és a pszichológiai szakirodalomban az ismeretek elsajátításával, tanulásával és a kognitív fejlődéssel kapcsolatban. Az 1970-es évek végén, az 1980-as évek elején az ismeretelméletben, tudományfilozófiában bekövetkezett változások 
és a kognitív pszichológia eredményei együttesen vezettek el a tanulás új szemléletéhez. E felfogás szerint az ismeretszerzés aktív folyamat, amelyben a tanuló nem passzív befogadó, hanem aktív szereplő, aki az őt körülvevő világról elméleteket és modelleket alkot. Az új információkat a meglevő, rendszerezett ismeretei segítségével értelmezi és sajátítja el. A gyerekek már az iskolába lépés előtt rendelkeznek naiv előzetes tudással a világról, ami interakcióba lép az iskolában szerzett új tudással. Ez az előzetes tudás azonban nemcsak kiindulási alapja lehet a tudományos ismereteknek, hanem akadályozhatja is a tanulást, ha összeegyeztethetetlen az új ismeretekkel. Sok esetben a tanulók iskolázás előtti fogalmai és a tudományos fogalmak minőségileg eltérő fogalmi rendszerbe ágyazódnak be. A tudományos fogalmak és alapelvek tanulása ezért rendszerint megköveteli a tanulók már meglevő, iskolázás előtti fogalmainak nagymértékủ átszervezését. Tág értelemben tehát a fogalmi váltás az ismeretelsajátítás folyamatában a meglevő és az új információ kölcsönhatásának eredményeként lezajló folyamatot jelenti, míg szúkebb értelemben a tanulás egy aspektusára, a tanulók fogalmi keretében bekövetkezett változásokra, átszerveződésekre, fogalmi cserékre utal. Éppen ezért a fogalmi váltás kifejezéshez számos, egymástól kisebb vagy nagyobb mértékben eltérő jelentés kapcsolódik. Lényegesen különbözhet az egyes megközelítésekben, hogy mi is az, ami változik (fogalom, a fogalomnál kisebb tudáselem vagy a fogalmaknál nagyobb egységek), és a változás milyen természetű (gazdagodás, differenciálódás, finomodás, átszerkesztés, kicserélés) aszerint, hogy az egyes kutatók hogyan értelmezik a tudást, annak létrejöttét és reprezentációját.

A fogalmi váltás folyamatának feltárása nemcsak a tanuláselméleti megközelítésekben, hanem a tanítás gyakorlatában is fontos szerepet játszik, ezért a fogalmi váltás vizsgálata jelen van egyrészt a természettudományok tanításával kapcsolatos, másrészt a kognitív fejlődéslélektani kutatásokban is. Az előbbi megközelítés magát a tanulást értelmezi fogalmi váltásként, és azt hangsúlyozza, hogy a tanulók meglevő, a tudományos nézeteknek nem megfelelő fogalmait ki kell cserélni új, tudományos fogalmakra. A fogalmi váltás kognitív fejlődéslélektani kutatásai viszont rendszerint leíróak, és arra keresik a választ, hogy milyen természetű a változás és hogyan lehet előidézni. E kétféle kutatási irány keretében több különböző elmélet született a fogalmi váltás jelenségének leírására és értelmezésére. A továbbiakban ezek közül mutatunk be néhányat, először a természettudományos nevelés, majd a kognitív fejlődéslélektan területéről.

\section{A TANULÁS MINT FOGALMI VÁLTÁS: A FOGALMI VÁLTÁS MEGKÖZELÍTÉSE A TERMÉSZETTUDOMÁNYOK TANÍTÁSÁVAL KAPCSOLATOS KUTATÁSOKBAN}

Az 1970-es évek elején a természettudományok tanításával kapcsolatos kutatásokban - CAREY (1986) kifejezésével élve - „miniforradalom” zajlott le. Ennek okai között megemlíthetjük, hogy az USA-ban az 1960 és 1970 között lezajlott tantervi reform nem váltotta be a hozzá füzött reményeket, másrészt pedig egyre erőteljesebben érvényesült a tanulás konstruktivista megközelítése. A fordulat kulcsszava a 
megértés és az AUSUBEL (1968) által bevezetett értelmes tanulás (meaningful learning) volt. E nézet szerint a tanulás akkor értelmes, ha az nem csupán tények, izolált fogalmak megjegyzését, „bemagolását” jelenti, hanem gazdag kapcsolatokkal rendelkező ismeretrendszer kiépítését, amit később fel lehet használni új szituációk magyarázatára is. A tanulás sikerességét befolyásoló legfontosabb tényezőként AuSubel (1968) a tanuló előzetes tudását jelölte meg. Ahhoz azonban, hogy az értelmes tanulás a természettudományos képzés reális célja lehessen, pontosan meg kellett ismerni a tanulók iskolázás előtti és a tanulás hatására megváltozott fogalmi kereteit, valamint meg kellett érteni, mi történik akkor, amikor a diák megtanul valamit.

\section{TÉVKÉPZETEK, ALTERNATÍV FOGALMAK, NAIV ELMÉLETEK: A FOGALMI RENDSZER EMPIRIKUS VIZSGÁLATA}

Az 1970-es évek közepétől a pedagógiai kutatások egyik legnépszerűbb területe volt annak vizsgálata, hogyan értik meg a tanulók a tudományos jelenségeket, alapelveket, például a newtoni törvényeket (Clement, 1982; CARAmazzA, McCloskey, Green, 1981), és az olyan fogalmakat mint a gravitáció (GUNSTONE, White, 1981); a Föld mint bolygó (Nussbaum, 1979); a hő és a hőmérséklet (ERICKSON, 1979); vagy az anyagi részecskék (NoviCK, NuSSBAUM, 1981). A vizsgálatok számos esetben felszínre hozták a tanulók tévképzeteit, az olyan ismereteket, amelyek nem felelnek meg az elfogadott tudományos nézeteknek. Közismert például, hogy a gyerekek közül sokan gondolják úgy, hogy „nincsen mozgás egy erő hatása nélkül” (CLEMENT, 1982); vagy „az anyag folytonos” (Novick, NussBAum, 1981). A kutatások kezdetben főként a természettudományok egyes területeire, azon belül is a mechanikára irányultak, de később számos biológiai, kémiai, földrajzi és történelmi tévképzetet azonosítottak. - A természettudományos tévképzetek problémáját magyarul KOROM (1997), a történelmi tévképzetekét VASs (1997) tekinti át. - A további kutatások különböző életkorú és nemzetiségű tanulók körében, különböző témák esetén feltárták azt is, hogy a tévképzetek kitartó, az oktatásnak ellenálló képződmények (ANDERSON, SMITH, 1987). Egy másik jelenség, amelyre már PIAGET (1929) is felhívta a figyelmet, az, hogy a gyerekek naiv meggyőződései gyakran megfeleltethetők a tudománytörténet által is számon tartott modelleknek, elméleteknek. Például a „nincsen mozgás erő nélkül” tévképzet a középkori lendületelméletet tükrözi (CLEMENT, 1982).

A tévképzet elnevezés számos kutató szerint túlhangsúlyozza a diákok elképzeléseinek helytelen voltát, ezért a tanulók iskolai képzés előtti fogalmi rendszerét gyakran „előfogalmaknak”, ,alternatív fogalmaknak”, „naiv elméleteknek”, „intuitív elméleteknek” vagy "gyermeki tudománynak” nevezik (GILBERT, WATTS, 1983). Azonban mindegyik terminus ugyanarra a jelenségre utal: a tanulók tévképzetei nem egyszerű hibák. A diákoknak számos tudományos fogalomra van leíró és magyarázó rendszerük a hétköznapi világ jelenségei alapján, ami jelentősen befolyásolja az iskolában tanított tudományos ismeretek megértését. Ezt már jóval korábban PIAGET (1929) is kimutatta a természeti jelenségekről adott tanulói 
magyarázatok elemzése során. Az elmúlt tizenöt év alatt folytatott több mint kétezer, a tanulók alternatív fogalmi kereteivel foglalkozó vizsgálat (PFUNDT, DUIT, 1991) további terjedelmes bizonyítékot szolgáltatott arra, hogy a diákok másképpen strukturálják a világot, a sémáik különböznek a tudományok képviselőinek sémáitól. Éppen ezért a hagyományos természettudományos képzés a tanulók nagy részénél nem tudja elérni az értelmes elsajátítást (NuSSBAUM, NoviCK, 1982; Champagne, Gunstone, Klopfer, 1985). A tanulók a tudományos alapelveket és fogalmakat gyakran csak memorizálják, de alkalmazni nem tudják azokat, és inkább kitartanak az iskola elótti fogalmaik mellett. Gyakran két inkonzisztens megközelítést - hétköznapi és iskolai - hordoznak, amelyet a megfelelő kontextusban egymástól függetlenül alkalmaznak. Az empirikus bizonyítékok egyre sürgetőbbé tették, hogy a hagyományos oktatási módszerekkel szemben kidolgozzák azokat a stratégiákat, amelyek elősegítik az értelmes fogalmi megértést (ANDERSON, SMITH, 1987; RoTH, 1990). Mindehhez azonban szükség volt egy olyan tanuláselméletre, amely leírja és megmagyarázza azokat a folyamatokat, amelyek révén a tanulók a központi, szervező fogalmaikat átfordítják egy másik, az előzővel inkompatíbilis fogalmi rendszerbe.

\section{A FOGALMI VÁLTÁS MINT A RÉGI FOGALMAK KICSERÉLÉSE: POSNER, STRIKE, HEWSON ÉS GERTZOG (1982) ELMÉLETE}

A tanulásnak új szemléletű, a megértést középpontba helyező megközelítéséhez és gyakorlatba való átültetéséhez az elméleti alapot az a tanulási modell jelentette, amely részben a tudományos ismeretek evolúciójának episztemológiai modelljein, részben pedig Piaget kognitív fejlődéselméletén alapult. A tanulást párhuzamba állította a tudományos ismeretszerzés folyamataival és a tanulóra mint tudósra tekintett. E tanulásimodell-felfogáson alapult a fogalmi váltás első és talán legnagyobb hatású elmélete, amelyet a Cornell Universityn dolgozott ki egy, a természettudományos neveléssel foglalkozó kutatókból és tudományfilozófusokból álló csoport (Hewson, 1981; Posner, Strike, Hewson, Gertzog, 1982; Strike, POSNER, 1982, 1985). Elméleti keretük központi gondolata az, hogy a tanulás racionális tevékenység, amely a tudományos nézetek megértése és elfogadása felé mutat, mivel azok értelmesnek és ésszerűnek tűnnek a tanuló számára.

A tanulás tehát egyfajta nyomozás, vizsgálat, amely során a tanulók döntéseket hoznak a hozzáférhető bizonyítékok alapján. A racionalitás alatt az elmélet kidolgozói olyan feltételeket értenek, amelyek révén az egyén megváltoztatja gondolkodását. Így a tanulás fogalmi váltás elméletével alternatívát adnak az empirizmussal szemben, amely korábban vezető nézet volt a filozófiában és a tudományfilozófiában. Az alapvető kérdés, amire a választ keresik az, hogyan változnak meg a tanulók fogalmai az új nézetek és bizonyítékok hatására.

Ismeretelméleti háttérként a kortárs tudományfilozófia nézetei szolgáltak, mindenekelőtt KUHN (1984) munkája a tudományban lejátszódó paradigmaváltásról. Kuhn nagy hatású elméletében a tudomány két létezési módját különbözteti meg, a normális és a forradalmi állapotot. A normális időszakban egy bizonyos 
fogalmi keret, paradigma dominál az adott tudományterületen. Amikor már túl sok hiányosság halmozódik fel a régi paradigmával kapcsolatosan, eljön a forradalmi szakasz, és a régi paradigmát új paradigma váltja fel, majd újra a normális szakasz következik. Ilyen váltás volt például a kopernikuszi fordulat, amikor a geocentrikus világképet felváltotta a heliocentrikus világkép, vagy amikor a newtoni elméletet követte a relativitáselmélet. POSNER és munkatársai (1982) szerint analógiát lehet létesíteni a tudomány fejlődése és az egyén esetében végbemenő fogalmi fejlődés között. Amíg a tanuló aktuális fogalmi kerete megfelelő az új jelenségek tanulmányozásához, addig a fogalmi váltás asszimilációs időszaka tart. Amikor a tanuló fogalmai már nem teszik lehetővé az új fogalmak megértését, a tanuló kénytelen kicserélni vagy átszervezni központi fogalmait. A fogalmi váltásnak e radikálisabb formáját akkomodációnak nevezik. WEST terminológiája szerint, amelyet GILBER és WATTS (1983) idéz, az asszimiláció az evolúciós változás (conceptual change), míg az akkomodáció a forradalmi változás (conceptual exchange). Bár az asszimiláció és az akkomodáció PIAGET (1970) terminusai, ez a megközelítés nem akar közvetlenül kapcsolódni Piaget elméletéhez. PosNER és munkatársai (1982) elismerik Piaget kutatásainak jelentőségét a kognitív struktúrák átszerveződésének megértésében, de amíg Piaget a fogalmi váltást a kognitív struktúra általános, tartalomtól független modifikációjának tekintette, ők az egyes specifikus tartalmak esetében bekövetkezett fogalmi cserékre koncentrálnak. Elsősorban az akkomodációt, a fogalmi váltás radikális típusát vizsgálják, és két kérdésre keresik a választ: 1) milyen feltételek esetén cserélődik ki egy régi központi fogalom új fogalomra, illetve 2) mi irányítja az új fogalmak kiválogatását. Az akkomodáció létrejöttéhez négy feltételnek kell teljesülni:

1. Az egyénnek elégedetlennek kell lennie az aktuális fogalmaival. Az elégedetlenség legfontosabb forrása az lehet, ha az egyén összegyűjti azokat a problémákat, amelyeket nem tudott megoldani a meglevő ismeretei alapján.

2. Az új fogalomnak érthetőnek kell lennie. Az egyénnek rá kell jönnie, hogyan tudja az új fogalom révén hatékonyan strukturálni tapasztalatait.

3. Az új fogalomnak hihetőnek, valószínűnek kell tűnnie.

4. Az új fogalomnak azt kell sugallnia, hogy hasznos lesz a későbbi vizsgálódások során is.

Az akkomodáció feltételeinek megvalósulását az egyén aktuális fogalmi készlete, fogalmi ökológiája teszi lehetővé. A fogalmi ökológia bizonyos elemei különösen nagy szerepet játszhatnak az akkomodáció feltételeinek létrejöttében és az új, hatékonyabb fogalmak keresésében. Ilyenek például az anomáliák, az analógiák vagy a metaforák.

\section{Pedagógiai következmények}

Az akkomodáció a világról alkotott alapvető feltevések radikális átszervezésével jár, de ez nem jelenti egyben azt is, hogy ez a váltás hirtelen, egyik pillanatról a másikra belátásszerűen megtörténik. A legtöbb esetben, főként az adott területen 
újoncoknál inkább fokozatos, több lépésből álló folyamat, gyakran sok-sok hibával és kitérővel járó útkeresés, amely megfelelő pedagógiai eszközökkel megkönnyíthető. POSNER és munkatársai (1982) hangsúlyozzák, hogy a fogalmi váltás elősegítéséhez változtatni kell az oktatás tartalmán és módszerein. Olyan tartalmakat kell tanítani, amelyek tudatosítják az adott tudományos elmélet alapvető explicit és implicit feltevéseit, megismertetik a tanulókat a modern tudomány episztemológiai alapelveivel és a tudománytörténettel. A tanulóknak meg kell tanítani olyan vizsgálati módszereket, elemzési eljárásokat, amelyek segítségével felismerik és megértik az anomáliákat. Ki kell alakítani az igényt a tanulókban, hogy konzisztenciát teremtsenek a világról való meggyőződéseikben. A tanárnak időt kell fordítania arra, hogy diagnosztizálja a tanulók gondolkodásában megjelenő hibákat, és feltárja az akkomodációt gátló védekező mechanizmusokat. Segítenie kell a tanulókat a tartalmak megértésében azáltal, hogy az adott ismeretet különböző szinten és reprezentációban (képi, verbális, konkrét praktikus, absztakt matematikai) jeleníti meg. Olyan helyzeteket kell találnia (problémafelvetés, kísérletek), amelyekkel kognitív konfliktus kelthetô a diákokban. A tanár hagyományos szerepe tehát módosul, egyrészt szókratészi módszert alkalmazó tutor, aki konfrontálja a tanulókat azokkal a problémákkal, amelyek az új fogalom asszimilációs kísérletei során jelentkeznek, másrészt modellt nyújt a tudományos gondolkodáshoz. Ez azt jelenti, hogy könyörtelenül megköveteli a konzisztenciát a meggyőződések, az elméletek és az empirikus tapasztalatok között. Szüntelenül kutatja a kevésbé hatékony meggyőződéseket, és szkeptikus a „kivétel erősíti a szabályt” megközelítéssel kapcsolatban.

\section{Az elmélet hatása}

A Posner és munkatársai (1982) által kidolgozott elméleti keret a kutatásokat irányító, vezető paradigmává vált a természettudományok tanításában. Népszerủ lett a tanuló mint tudós metafora (Nussbaum, 1989; WANDERSEe, 1985). Széles körben elterjedt a tanulás fogalmi váltásként való értelmezése és a fogalmi váltást elősegítő tanítás, amely explicit célként tűzte ki, hogy a tanárnak olyan feltételeket kell teremtenie, amelyek segítségével a diákok tudatosan megtapasztalják a fogalmi váltást bizonyos témák tanulása során (ROTH, 1990; HEwSON, BEETH, THORLEY, 1998). Ahhoz, hogy a tanulók a régi nézetekkel elégedetlenek legyenek, és belássák, hogy az új nézetek hasznosabbak és hatékonyabbak, a legmegfelelőbb tanítási stratégiának a tanulók meglevő fogalmai és az új fogalom közötti kognitív konfliktusok keltése tűnt. A posneri elméleti keret megerősítést, igazolást adott a kognitív konfliktusok (piageti terminológiával az egyensúlyra való törekvés) oktatásban való használatára (VOSNIADOU, SCHNOTZ, 1997). A kognitív konfliktus vagy kognitív disszonancia sokféle módon előidézhető: kritikus kérdések, problémák felvetésével, vita indukálásával (ANDERSON, SMITH, 1987; CHAMPAGNE, GUNSTONE, KLOPFER, 1985); a tanulókat foglalkoztató nézetek, rejtélyek leírásával (KUHN, AGUIRRE, 1987); analógiákkal, számítógépes szimulációkkal (ClEMENT, 1993; BRNA, 1988; FINEGOLD, GORSKY, 1988), fogalmi differenciációval és cseré- 
vel (Hewson, P. W., Hewson, M. G., 1984), tanulói kísérletekkel (STEPHANS, 1996). A kognitív konfliktusok keltése azonban csak akkor lesz sikeres, ha a tanár valóban törekszik arra, hogy megértse a gyermeki tudományt (GILBERT, OsBORNE, FENSHAM, 1982), és támogató, bizalmas osztálytermi légkört teremt, amelyben a diákok gátlások nélkül elmondhatják elképzeléseiket az adott problémával kapcsolatban (WATTS, BENTLEY, 1987).

\section{Az elmélet kritikája}

Napjainkban a fogalmi váltás legelső elmélete - CARAVITA, HALLDÉN (1994) terminusában az „alternatív fogalom paradigma” - számos kritika tárgya. Egyetlen vizsgálat sem erősítette meg az akkomodáció teljes megvalósulását. A tanulók meglevő fogalmait nem lehet teljesen megszüntetni, és a tudományos nézettel helyettesíteni (CHINN, BREWER, 1998). A kognitív konfliktusok keltése, az anomáliás adatok, tények prezentálása nem szükségszerűen vezet el a tanulók nézeteinek megváltoztatásához, mivel a tanulók az anomáliás adatokat, tényeket gyakran csupán egyszerű kivételnek tekintik (LIMÓN, CARRETERO, 1997).

A tévképzetek nem cserélődnek le, hanem együtt léteznek az új fogalmakkal és bizonyos kontextusokban „életben maradnak”, míg más esetekben a kezdeti meggyőződések egyesülnek az új nézetek bizonyos részeivel, és ezáltal „hibrid” nézetek jönnek létre (CARAVITA, HALldÉN, 1994; PFUndT, DUIT, 1991). DUIT és TREAGUST (1998) kiemelik, hogy a régi ideák törlése nemcsak lehetetlen, de nem is kívánatos. A tanulóknak ugyanis számos olyan fogalmuk van, ami jól használható a hétköznapi szituációkban. Ezért inkább azt kellene tudatosítani a tanulókban, hogy bizonyos kontextusokban a tudományos fogalmaik eredményesebben használhatók, mint saját hétköznapi fogalmaik.

Az elmélet központi, „a tanuló mint tudós” metaforáját CARAVITA és HALLDÉN (1994) elemzi. Ök vitatják, hogy az alkalmas lenne a fogalmi váltás és a tanulás megértésére. Szerintük nagyon fontos különbségek vannak a diszciplináris tudás története és az iskolai tanulás során történő ismeretszerzés között. A kétféle ismeretszerzés párhuzamba állítása kiragadja a fogalmi váltást az iskolai tanulás komplex folyamataiból. Másrészt nem értenek egyet a tudásreprezentáció statikus dimenziójával sem. Az alternatív fogalom paradigma, illetve a hozzá szorosan kapcsolódó, a fogalmi rendszert és annak változását analizáló hagyományos pedagógiai kutatások módszerei (a kezdeti és a végállapot értékelése, fogalmi térképezés) a tudáskonstrukció lineáris folyamatként való értelmezését sugallják. Eszerint az ismeretelsajátítás szükségszerűen, lépésről lépésre halad a tudományos standardok felé. Közben a tanulók fogalmai gazdagodnak, illetve kicserélődnek, helyettesítődnek. E megközelítés mögött a propozicionális tudásreprezentáció nézete húzódik meg, amely szerint a tanulók fogalmi keretei a hosszú távú memóriában csomópontok és kapcsolatok formájában reprezentált entitások. Az ismeretszerzés során e rendszer strukturáltságának, hierarchikus szervezettségének növelése a cél. Ezzel szemben CARAVITA és HALLDEN (1994) a tudásstruktúra dinamikus jellegét, a fogalmak kontextustól és szituációtól függő „vibráló” státusát és életlen 
határait hangsúlyozzák. Véleményük szerint a tudáskonstrukció folyamata nem lineáris. Egy bizonyos fogalom, nézet megértése hosszú idő alatt fejlődik ki számos eltérő (empirikus, elméleti és gyakorlati) kontextus, különböző absztrakciós szintű reprezentáció és sokféle tanulási stratégia alkalmazása révén.

Ezek a kritikák összhangban vannak a tudományfejlődés kuhni értelmezésének bírálatával (LAKATOS, 1968). A paradigmák, a kutatási programok nem cserélhetők fel tökéletesen egymással. A fejlődés inkább a versengő kutatási programok közötti racionális választásban rejlik.

A „tanulás mint fogalmi váltás” elmélet egy másik korlátjára hívja fel a figyelmet PiNTRICH, MARX és BOYLE (1993). A „hideg” jelzővel szemléletesen mutatnak rá arra, hogy ez a megközelítés túlzottan racionális, és csak a kognitív tényezőkre koncentrál. A fogalmi váltás sikere ugyanis nagymértékben függ az affektív tényezőktől, a tanuló érdeklődésétől, motivációjától is. A PINTRICH és munkatársai (1993) által képviselt nézet tudományfilozófiai előfutárának tekinthető POLÁNYI (1958) „személyes tudás” felfogása, amely szerint az egzakt tudományoknak tulajdonított tökéletes objektivitás hamis elképzelés. A megismerés során ugyanis a tényszerű ismereteket a megismerő személy személyes tudása (intellektuális képessége, szenvedélyes részvétele, közösséghez való tartozása, kulturális háttere) formálja.

\section{A FOGALMI VÁLTÁS KOGNITÍV FEJLŐDÉSLÉLEKTANI MEGKÖZELÍTÉSEI}

Az utóbbi évtizedben számos pszichológus, pedagógiai kutató próbálta precízebben megfogalmazni az interakciót az előzetes és az új tudás között a kognitív pszichológiából és a kognitív fejlődéslélektanból vett fogalmak alapján. A kognitív pszichológia egyik alapvető megállapítása, hogy az ember gondolkodási sémái, ismeretei nem általánosítódnak automatikusan, hanem inkább tartományspecifikusak, azokhoz a kontextusokhoz kötődnek, amelyekben az elsajátításuk történt. Számos kutató vallja ezért azt a nézetet, hogy a fogalmak gazdag tartományspecifikus (domain-specific) elméletekbe ágyazottak, és így az ismeretszerzés folyamatát az egyes specifikus tantárgyi területeken vizsgálják.

Mindez ellentétben áll a kognitív fejlődés korábbi, PIAGET (1970) által képviselt elméletével, amely szerint a fogalmi váltás a kognitív struktúra általános modifikációja, amely befolyásolja a tudás megszerzésének folyamatát az összes tantárgyi területen. Piaget elméletében a kognitív fejlődést a kognitív konfliktusok elkerülésére tett kísérletek ösztönzik, ugyanis az elme a kiegyensúlyozott mentális állapot elérésére törekszik. VOSNIADOU és SCHNOTZ (1997) rámutatnak, hogy Piaget elmélete a fogalmi váltást globális átrendeződésként írta le, és nem tudta megmagyarázni azt a sok nehézséget, amivel a gyerekek küzdenek azért, hogy eredeti tudásstruktúráikat módosítsák. A fogalmi váltás fejlődéslélektani tanulmányozásában azonban fontos kiindulási alap mindaz az óriási mennyiségű empirikus adat, amelyet Piaget és munkatársai gyújtöttek arról, milyen elgondolásokat, elméleteket hoznak létre a gyerekek az őket körülvevő világról, valamint az a megállapítás, 
hogy a gyerekek tudása alapvetően különbözik a felnőttek tudásától (PIAGET, 1929; INHELDER, PiAGET, 1967; PiAGET, 1970). A különböző életkorú gyerekek és az iskolázatlan, illetve iskolázott felnőttek tudásának feltérképezése a kognitív fejlődéssel foglalkozó kutatók körében is nagy szerepet kap.

\section{A GONDOLKODÁS TARTOMÁNYSPECIFIKUS ALAPELVEI ÉS VÁLTOZÁSUK A KOGNITÍV FEJLŐDÉS SORÁN}

Az utóbbi években egyre több kognitív fejlődéspszichológus ért egyet azzal, hogy az emberi elme különböző, tartományspecifikus megkötések alapján működik, reflektálva az evolúció során felmerült adaptációs problémákra (COSMIDES, TOOBY, 1994). A tartományspecifikus tudás fejlődését és a gyermekkorban lezajló változásokat vizsgáló kutatásokat CAREY és SPELKE (1994) tekinti át és kiemeli, hogy az emberi gondolkodást tartományspecifikus alapelvek irányítják legalább három területen: a fizika, a pszichológia és a számok világában. Mindhárom tudásrendszert olyan központi alapelvek jellemeznek, amelyek meghatározzák azokat az entitásokat, amelyekkel az adott tudásterület foglalkozik, és irányítják az entitásokról való gondolkodás módjait. A csecsemők az egységet, a határokat, a komplett alakzatokat, az általuk látott és érzékelt tárgyak megmaradását olyan alapelvek alapján érzékelik, mint a kohézió, a kontaktus vagy a folytonosság. A pszichológia területén fontos alapelv az, hogy az emberek cselekvéseik alapján azonosítják az élő dolgokat, és nem a külsejük analizálásával. A számokkal kapcsolatos tudás pedig magában foglalja az „egy az egyhez megfelelés” és a szukceszszió alapelvét (minden számnak egyetlen utódja, rákövetkezője van).

A fizikai objektumokról, az emberekről és a számokról való tudásunk nemcsak gazdagodás révén növekszik. A tudománytörténet során jelentkező fogalmi váltások ugyanis bizonyítékot jelentenek arra, hogy a gondolkodásnak nincsenek olyan univerzális, központi alapelvei, amelyek ellenállnának a változásnak, a kulturális hatásoknak. A tudományos ismeretek növekedése és az egyén kognitív fejlődése során megváltoznak az alapelvek, és az előzőekkel összemérhetetlen, új alapelvek jönnek létre.

\section{Fogalmi váltás gyermekkorban}

A kognitív fejlődéslélektannal foglalkozó kutatók hatalmas mennyiségű adatot szolgáltattak az emberi elme természetéről, a tudás szerveződéséről és változásáról. A kisgyermekek intuitív tudásában bekövetkező fogalmi váltásokról Carey és Spelke (1994) áttekintése alapján ismertetünk példákat az intuitív számfogalommal, néhány biológiai fogalommal és az anyag fogalmával kapcsolatosan.

Az intuitív számfogalom változása

Az iskola előtt a gyerekek a pozitív egész szám fogalmával rendelkeznek, amit a dolgok megszámolásából eredő alapelvek - „egy az egynek való megfelelés” és a 
„szukcesszió” - alakítanak ki. Ez azt jelenti, hogy a 4-7 éves gyerekek tudják azt, hogy a számokat akkor használjuk, amikor meg akarunk számolni valamit, és a megszámlálandó dolgoknak megfeleltethetők az egyes számok, továbbá minden számot egy másik követ $(1,2,3 \ldots)$. Az iskolai évek alatt ez a számfogalom kiegészül a nulla, majd a végtelen és a racionális számok fogalmával. A nulla fogalmának megértése és annak megismerése, hogy nincs legnagyobb szám, váltást jelent a számolásból a szeparált számok felé. Ugyancsak fogalmi váltást igényel a racionális szám fogalmának létrejötte is. Ahhoz, hogy a 0,5-öt és az 1/3-ot számként tekintse a tanuló, fel kell adnia a számoknak számolás révén való azonosítását és a szukcesszió alapelvét. Két racionális szám között ugyanis végtelen sok szám van. A kisiskolásoknak sokáig gondot jelent a törtek sorba rendezése nagyság szerint, mert a számokkal kapcsolatos, a megszámlálásból eredő implicit alapelveik gátat szabnak az osztás és a törtek megértésének (HARTNETT, GELMAN, 1998).

Az intuitív biológia

CAREY (1985) szerint a fiatal gyerekek intuitív biológiája - a biológiai jelenségekkel kapcsolatos, más területektől elkülönült tudásrendszere - csak 10 éves korukra válik külön az intuitív pszichológiai ismereteiktől. Ez az elkülönülés számos fogalom értelmezésében, megértésében hoz változást. Carey esettanulmányában 4 és 10 éves kor között mutatja be a biológiai tudás szerveződését, és számos jelenségen keresztül érzékelteti azt, hogy a gyerekek tudása az állat, növény, ember, élő dolog fogalmak esetében a gyermekkor során átrendeződik. Például tízéves korra megszűnik az animizmus. Ekkorra a gyerekek élőnek tekintik nemcsak az állatokat, hanem a növényeket is, valamint az állatokat biológiai és nem viselkedési létezőnek tartják. Tízéves korukig a gyerekek a biológiai jelenségeket pszichológiai okokkal magyarázzák. A kisgyerekek nem tudják elkülöníteni a biológiai jelenséget a pszichológiaitól, és nem képesek felismerni, hogy olyan biológiai folyamatok, mint például a növekedés vagy a légzés függetlenek a pszichológiai tényezőktől, az ember akaratától.

Később CAREY (1995) az intuitív biológia kialakulásának életkori határát 10 éves korról 6-7 éves korra tette, és módosította azt a nézetét, hogy a gyerekek minden biológiai megfigyelést eltorzítanak azért, hogy az illeszkedjen az intuitív pszichológiájukhoz. KEIL (1994) a biológiai gondolkodás elkülönülését korábbra, 4 és 7 éves kor közé teszi. CAREY (1985) elméletével szemben azt állítja, hogy a fiatal gyerekek iniciális biológiai tudása nem pszichológiai eredetű, hanem a kezdetektől elkülönülő biológiai elmélet eredménye, és ezért még a 6 évesnél fiatalabb gyerekek gondolkodásában is van egy független biológiai terület. Szerinte a fogalmi váltás az intuitív biológia területén belül zajlik, viszont egyáltalán nem részletezi, hogy milyenek ezek a változások.

HATANO és INAGAKI (1997) egyetértenek KeIL (1994) azon nézetével, hogy az intuitív biológia önálló ismeretrendszer, ami öröklött megszorítások alatt áll és már a 6 évesnél fiatalabb gyerekeknél is elkülönül az intuitív pszichológiától. KEIL (1994) felfogásával ellentétben HATANO és INAGAKI (1997) azonban nem gondolja azt, hogy a fiatal gyerekek iniciális tudása teljesen mentes a pszichológiai tényezőktől. Véleményük szerint a fiatal gyerekek biológiája fokozatosan konstruálódik 
a mindennapi tapasztalatok alapján, és később jön létre, mint az intuitív fizikájuk vagy az intuitív pszichológiájuk. Így az iniciális biológia kialakulását befolyásolják a más területeken korábban megszerzett ismeretek is, például a gyerek pszichológiai elképzelései. INAGAKI (1997) vizsgálatai alapján úgy gondolja, hogy a naiv biológia a naiv pszichológiától már nagyon korán, 4 éves korra elkülönül a gyerekek gondolkodásában, de időnként még a pszichológiai és szociális ismereteiket használják a gyerekek a biológiai magyarázatokhoz. Például nemcsak a fiatalabb, de a 6 éves gyerekek közül is sokan gondolták úgy, hogy „az a gyerek, aki veri a társait és hazudik, könnyebben lesz náthás, mint az, aki jól viselkedik”.

HATANO és INAGAKI (1997) a gyerekek naiv biológiájában bekövetkezett minőségi változások közül kettőt emel ki. 1) A fiatal gyerekek az élő dolgok viselkedésének, jellemző tulajdonságainak előrejelzésében az adott dolgot az emberhez hasonlítják, míg az idősebb gyerekek és a felnőttek az adott dolog kategóriájának tulajdonságait használják. A kisgyerekek az emberekkel kapcsolatos tudásukat nem használják elkülönülten. Például egy ötéves gyerek szerint „a nyuszi nem lehet örökké kicsi, mert ha én lennék a nyuszi, akkor ötéves lennék, és egyre nagyobb lennék". 2) Míg a fiatalabb gyerekek a vitális magyarázatokat részesítik előnyben, addig az idősebbek a mechanisztikusakat. Míg CAREY (1985) szerint a kognitív fejlődésben a szándékos okságot a mechanisztikus okság követi, addig HATANO és INAGAKI (1997) feltételeznek egy közbülső állapotot is, a vitális okságot. A szándékos okság azt jelenti, hogy az egyén akarata az oka az adott jelenségnek (pl. növekedés). A mechanisztikus okság a biológiai jelenségeket fiziológiai mechanizmusokkal magyarázza, míg a vitális okságnál a jelenség oka egy adott belső szerv tevékenysége. A tevékenység alatt vitális erő, anyag, energia vagy információ átadását, illetve kicserélését kell érteni (a 6 éves gyerek szerint „,azért van szükség a levegőre, mert belőle a mellkasunk életerőt vesz fel” vagy „ha nem eszünk, akkor az energia el fog tűnni, és meg fogunk halni”).

A fiatal gyerekek és a laikus felnőttek intuitív biológiája közötti különbségek HATANO és INAGAKI (1997) szerint: a gyerekek ténybeli tudása kisebb, hiányzik a komplex, hierarchikusan szervezett biológiai kategóriák alapján történő következtetés, hiányzik a mechanisztikus okság; hiányoznak az alapvető fogalmak (például evolúció, fotoszintézis). Ahogy a gyerek növekszik, a megszemélyesítő és vitális biológiája fokozatosan alakul át a kategória alapú következtetésekre épülő, a mechanisztikus oksági magyarázatokat előnyben részesítő és a szándékos okságot elvető „pszichológiamentes” biológiává.

Az anyag fogalma az intuitív fizikában

CAREY és SPELKE (1994) idézik Carey korábbi vizsgálatait, amelyek megmutatták, hogy az iskoláskor kezdetén a gyerekek már képesek elkülöníteni az anyagi és a nem anyagi dolgokat, de az anyagról alkotott fogalmuk nem összemérhető a felnőttekével. Jelentős fogalmi váltás zajlik le 4 és 12 éves kor között az anyag, anyagfajták, súly, sűrűség és a levegő fogalmak esetében. Az anyagokról, dolgokról való gondolkodást az iskoláskor előtt három alapelv irányítja. 1) A kontinuitás alapelve szerint adott pillanatban a tér bizonyos részét az anyagnak csak egy része foglalhatja el. 2) A láthatóság alapelve szerint az anyagi dolgok közvetlenül megfi- 
gyelhetők. 3) A kontaktus alapelve pedig arra utal, hogy az anyagi dolgok oksági kapcsolatban állnak egymással.

A felnőttekkel ellentétben a kisgyerekek a súlyt nem az anyag esetleges tulajdonságának tekintik. Bizonyos anyagoknak van súlyuk, másoknak pedig - mint például egy borsónyi szappanhabnak - egyáltalán nincs. Mivel a súly a gyerekek számára nem fontos tulajdonsága a dolgoknak, ezért az anyag mennyiségének meghatározását sem tudja segíteni. A gyerekeknél differenciálatlan a súly (mint extenzív mennyiség) és a sűrűség (mint intenzív mennyiség) fogalma. A súly és a sűrűség differenciálódásában fontos szerepe van a folytonos és homogén anyagmodell kialakulásának. Ez a nézet fennmaradhat az anyag részecske természetét hangsúlyozó oktatás ellenére is.

Kezdetben ugyancsak differenciálatlan a levegő és a „semmi” fogalma. Például a négyéves gyerekek és a 6-10 éves korosztály jelentős hányada szerint egy dobozban, amely tele van apró fémkockákkal, ugyanolyan térfogatú levegő is lehet egy időben, mert a „levegő semmi”. Ugyanezek a gyerekek viszont azt mondják, hogy „szükség van levegőre a légzéshez”, „a szél levegőből van”. Más interjúkban viszont, ahol korábban nem esett szó a levegőről, a gyerekek egynegyede mondta azt, hogy „a levegő olyan anyagból van, mint amiből az álom”.

A gyermekkorban lejátszódó fogalmi átszerveződések egyértelmủen bizonyítják, hogy téves az az elképzelés, amely szerint csak egyes tudósok, a tudománytörténet korszakalkotó alakjai képesek arra, hogy megdöntsék a gondolkodást alapvetően determináló, öröklött alapelveket. A gyerekek is képesek arra, hogy megváltoztassák tartományspecifikus ismereteik központi alapelveit. A változások egy része univerzális, de vannak kultúrafüggőek is. Erre ad szemléletes példát VOSNIADOU (1994a) az asztronómiai jelenségekről alkotott mentális modellek bemutatásával.

A gyerekek mentális modelljei a Földről, a Napról, a Holdról

és a nappal/éjszaka ciklusról

VOSNIADOU és munkatársai kultúraközi vizsgálataikban amerikai, görög, indiai, szamoai és indián gyerekekkel (óvodás kortól 12 éves korig) készítettek interjúkat a Föld alakjáról, helyzetéről, a nappal/éjszaka ciklusról (VOSNAIDOU, BREWER, 1990; Vosniadou, 1994a; DiakidoY, Vosniadou, HAWKs, 1997). A gyerekek szóban válaszoltak, rajzoltak vagy agyagból modelleket készítettek. A kutatók feltételezték, hogy a kérdések megválaszolásához a gyerekek olyan egyéni mentális modelleket hoznak létre meglévő tudásbázisuk alapján, amelyek tükrözik azt a fogalmi struktúrát, amelybe fogalmaik beágyazódtak. Például a gyerekek a Földre vonatkozó ismereteik alapján létrehozzák a Föld mentális modelljét, hogy megválaszolják azt a Föld alakjával kapcsolatos kérdést, hogy: „Ha nagyon sokáig mennénk egyenes irányban, eljutnánk-e a Föld végére?” A mentális modell ebben az esetben olyan dinamikus és generatív analóg reprezentációt jelent, amelyet az egyének hoznak létre vagy hívnak elő a kognitív működés során, amely megőrzi a tárgy struktúráját és mentálisan manipulálható azért, hogy bizonyos fizikai jelenségeket vizsgálni lehessen. 
Az interjúk eredményei azt jelzik, hogy a gyerekek ugyanolyan iniciális, majd az iskolai tanulmányok hatására ugyanolyan szintetikus és tudományos modelleket alkotnak, függetlenül attól, milyen kultúrában nevelkedtek. E tapasztalat arra utal, hogy az asztronómiai jelenségek magyarázatait kialakító, öröklött tartományspecifikus alapelvek univerziálisak. A gyerekek iniciális modellje a Földről az, hogy „a Föld lapos; alá van támasztva; mozdulatlan; nagyobb, mint a Nap és a Hold; a Föld az univerzum középpontja”. E modell létrejöttét olyan ontológiai alapelvek determinálják, mint a fizikai objektumokra jellemző szilárdság, állandóság, a felülről lefelé (és nem a Föld középpontja felé) ható gravitáció. Amikor a gyerekek iskolába mennek, hallanak arról, hogy a Föld gömb alakú bolygó, ami forog és kering a Nap körül; sokkal kisebb, mint a Nap és a csillagok és nem a Naprendszer középpontja. Az új ismeret megértése, elsajátítása lassan és fokozatosan, a megértés különböző szintjein halad keresztül az iniciális modellektől a tudományos felé. Az átmeneti állapotban jelennek meg a szintetikus modellek, amelyek a gyerekek kognitív erőfeszítéseinek eredményei azért, hogy asszimilálják a felnőtt nézeteket saját naiv elképzeléseikbe. Ilyen szintetikus modell például a „kettős Föld” modell (két Föld van, az egyik lapos, ezen élnek az emberek, a másik pedig egy gömb a világürben); a „lyukas gömb” modell (a Föld gömb alakú, de a belsejében van egy sík felszín, ott élnek az emberek); a „lapított Föld” modell (a Föld gömb alakú, de a teteje lapított, azon élnek az emberek).

Bár a különböző nemzetiségű részminták mindegyikében előfordultak az iniciális és a szintetikus modellek, a fizikai környezet vagy bizonyos kultúraspecifikus hatások módosíthatják az egyes modelleket. Például az indiai gyerekek szerint „,a Földet az óceán vize támasztja alá”, a görög gyerekek szerint inkább „a Földet egy ember hordozza a vállán”. Minkét elképzelés mitológiai elemek következménye (indiai kozmológia: a Föld alatt az óceán rétegzett: vizet, tejet és nektárt tartalmaz; a görög mitológiában a Földet Atlasz hordja a vállán). A szintetikus modellek közül a „duális Föld” modellt csak az amerikai gyerekeknél tapasztalták. A „lyukas gömb" modellt elsősorban a lakota/dakota indián gyerekek preferálták, mert az hasonlít a lakota mitológiában a Föld alakjának leírásához (a korong alakú Földet az ég kupolaként borítja be). Csak a szamoai gyerekeknél fordult elő a „gyürü alakú Föld” szintetikus modell. A gyerekek agyagból egy gyűrűt formáztak, közepén a korong alakú Földdel. A gyúrủ forma jelzi azt a területet, ahol az emberek élnek. Ez a modell annak következménye, hogy abban a szamoai faluban, ahol a megkérdezett gyerekek élnek, a társas tér ilyen alakban szerveződik. Gyűrű formájú a falu, a piac és a házak belseje is.

A nappal és az éjszaka váltakozására adott magyarázatok egyrészt animisztikusak voltak, másrészt szintén tükrözték a földrajzi és a kulturális különbségeket. A görög gyerekek szerint „,este a Nap eltűnik a hegyek, illetve a tenger mögött”; az amerikai gyerekek úgy gondolják, hogy „a Nap a Föld alá megy”; az indiai gyerekek szerint ,a Nap és a Hold állandóan üldözik egymást”.

E példák jól mutatják azt, hogy az ismeretszerzés folyamata az asztronómiában minden gyereknél hasonló utat követ, függetlenül a kulturális hatásoktól, de a kulturális kozmológia befolyásolja mind az egyes modellek konstrukcióját, mind pedig az asztronómiai jelenségek magyarázatának módjait. 
A gyerekek intuitív tudásában bekövetkezett változások leírása nagy jelentőséggel bír a fogalmi váltás kutatások kognitív fejlődéslélektani megközelítéseiben. A változások leírása azonban nemcsak a kisgyermekkorra és az iskoláskor kezdetére korlátozódik, hanem az iskolázás későbbi szakaszaira is. A szakértőség különböző szintjén, számos tantárgyi területen folynak olyan vizsgálatok, amelyek a kognitív fejlődést nyomon követik és a pedagógiai relevanciájuk is kiemelkedő (BLISS, Ogborn, 1994; Tiberghien, 1994; Lehtinen, Merenluoto, Kasanen, 1997; VOSS, WILEY, 1997).

\section{A FOGALMI VÁLTÁS KOGNITÍV ELMÉLETEI}

A kutatók egyetértenek abban, hogy a tanulók a mindennapi tapasztalataik alapján a világ hétköznapi megértését hozzák létre. Vita folyik azonban arról, hogy milyen a gyerekek naiv tudása, hogyan formálódik a fejlődés során, és milyen hatással van az iskolai tanulás a kezdeti ismeretekre. Az utóbbi évtizedben számos kutató próbálta leírni a fejlődés során bekövetkező fogalmi átrendeződés jellemzőit. E megközelítések közül négy elmélet különösen jól ismert. Az egyes elméleteket szinte egy időben dolgozta ki CAREY (1985), DiSesSa (1993), CHI, SlotTA, DE LEEUW (1994) és VOSNIADOU (1994b). Mint az a későbbiek során látható lesz, számos hasonlóság és különbség van közöttük. Az egyik legfontosabb szempont, ami alapján két csoportra lehet osztani a négyféle megközelítést az, hogy a gyerekek iskola előtti intuitív tudását elméletszerűnek tekintik-e vagy sem. CAREY (1985), CHI és munkatársai (1994) és VOSNIADOU (1994b) szerint a gyerekek koherens intuitív elméletet hoznak létre a világgal kapcsolatban, míg DISESSA (1993) szerint a naiv hétköznapi tudás fragmentált, izolált tudásdarabokból áll. A gyerekek naiv tudásában bekövetkezett változásokat viszont mindannyian másképpen magyarázzák.

\section{Gyenge és erös fogalmi átrendeződés: CAREY elmélete}

CAREY (1986) javasolta először a fogalmi váltás kifejezést a kognitív fejlődésben a gazdagodás nézettel szemben. Felhívta a figyelmet arra, hogy olyan területeken, mint a naiv fizika vagy az intuitív biológia a tudás nemcsak mennyiségileg növekszik, hanem a fejlődés során át is szerveződik. Az átszerveződés kétféle típusát, a gyenge és erős átrendeződést különböztette meg az újonc-szakértő váltás, illetve a diszciplináris tudás változása alapján.

A szakértővé válás folyamata:

az ismeretrendszer gyenge átszervezése

A kognitív pszichológiának a „tartalomhoz kötött tudás” nézete mellett a tudás hasznosíthatóságával és a szakértővé válással kapcsolatos eredményei is jelentős hatással voltak a kognitív fejlődés során bekövetkező változások értelmezésére. A 
szakértővé válás folyamata az emberi problémamegoldás számítógépes modellezésében az egyik legintenzívebben kutatott terület (MÉRŐ, 1994). Jelentős különbségeket mutattak ki a kezdők és a szakértelemmel rendelkező emberek tudásának mennyisége és minősége között, például a sakkozás vagy a fizikai problémák megoldása esetében. Az újonc-szakértő váltás területén végzett kognitív kutatásokat CHI, GLASER és REES (1982) tekinti át és a váltás leírására három módszert ismertet: (1) tévképzetek dokumentálása, (2) elemek közötti hasonlóságok elemzése (az újoncok a fizikai problémákat tartalmi szempontok, míg a szakértők a megoldásukhoz szükséges alapelvek szerint tekintik hasonlónak) és (3) a problémamegoldás információfeldolgozó analízise (sakkozás, fizikai feladatok megoldása). A pedagógiai és a kognitív pszichológiai kutatások által felhalmozott eredmények alapján az újoncok és a szakértők közötti átszerveződést úgy értelmezik, hogy a szakértők a fogalmak között más kapcsolatokat létesítenek, mint az újoncok. A létrejövő új kapcsolatok új fogalmak és sémák létrehozását indukálják, amelyek lehetővé teszik az új problémák megoldását és a régi problémák megoldásának megváltoztatását.

CAREY (1986) az újoncból szakértővé válás folyamatát gyenge átszerveződésként tekinti. A két fogalmi rendszer csomópontjai ugyanis változatlanok maradnak, a csomópontok és a kapcsolatok száma gyarapszik, de a kiindulási elmélet alapjában véve nem változik. Például így cserélődik ki a fizika területén újonc tanuló „nincs mozgás erő nélkül” nézete a „nincs gyorsulás erő nélkül” szakértői nézetre. A fogalmi rendszer szerkezetében, kapcsolataiban bekövetkezett változást szemléletesen jelenítették meg a pedagógiai kutatók a fogalmi térképezés technikával (NOVAK, 1990; MARKHAM, MINTZES, JONES, 1994).

A diszciplináris tudás fejlődése:

az ismeretrendszer erős átszerveződése

CAREY (1986) a tudománytörténetből vett példák alapján, elsősorban KUHN (1984) munkájára támaszkodva, a tudományos forradalom analógiájára értelmezte az egyének fogalmi rendszerében lezajló radikálisabb változásokat. Az erőteljes átstrukturálódás az egymást követő, szukcesszív elméletek, fogalmi rendszerek központi fogalmaiban történt változást jelenti. Emellett megváltozik a jelenségek köre, amellyel az adott elmélet foglalkozik, és az elfogadhatónak ítélt magyarázatok természete is. E három különbség az egymásra épülő elméletek között azt eredményezi, hogy az elméletek terminusai nem fordíthatók át egymásba. A mechanika szukcesszív elméleteiben például az erő, sebesség, idő, tömeg terminusok alapvetően megváltoznak. Az elméletek közötti váltás ezért nagyon nehezen történik meg. Az erős átszerveződés tipikus példája az arisztotelészi mechanikából a Galilei-féle mechanikába való átmenet, amikor is egyszerre történt változás a terület, a magyarázó struktúra és a központi fogalmak (mozgás, sebesség) esetében.

A fogalmi rendszer radikális átszerveződésének elmélete magyarázatot ad számos tévképzetre is. Például McCLOSKey (1983) röppályás vizsgálataiban a lövedék mozgásának magyarázatát kérte, és párhuzamot fedezett fel a tanulók elképzelései és a középkori, Galilei előtti lendületelmélet között. Mindkét esetben ugyanis az az alapvető elképzelés, hogy a tárgyakat belső és nem külső erők tartják mozgásban. 
Ez a meggyőződés természetes következménye a világ mozgó tárgyaival kapcsolatos tapasztalatoknak. A tévképzetek azért állnak ellen az oktatásnak, a mechanika tanulása azért olyan nehéz, mert az elméletváltásnak olyan fajtáját kívánja meg, sőt többet, mint amilyet Galilei elért: váltás a lendületelméletből a newtoni mechanikába.

A fogalmi váltás analízise számos esetben okoz gondot, hiszen a gyenge és erős átszerveződés elmélet nem adja meg azokat a kritériumokat, amelyek alapján el lehetne dönteni, hogy a változás melyik típusa megy végbe az adott esetben. Még napjainkban is nyitott kérdés az, hogy milyen folyamatok játszódnak le a gyenge és az erős fogalmi váltás folyamatában, és a tanulást lehet-e úgy tekinteni, mint az erős átstrukturálódásként értelmezett fogalmi váltás egy folyamatát. Az átszerveződés e kétféle, gyenge és erős típusának megkülönböztetését több kognitív fejlődéskutató elfogadja (CHI, SLOTTA, DELEEuw, 1994; Vosniadou, 1994b; HaTANO, INAGAKI, 1997). DiSESSA (1998) elméleti keretében viszont a gyenge és az erős fogalmi váltás nem megfelelő elkülönítés. Szerinte ugyanis bizonyos dolgok tanulása kiterjedtebb átszervezést igényel, mint másoké. A két szélsőséges kategóriára átszerveződés nélküli gazdagodás, illetve radikális átszerveződés - való leszúkítés helyett a változást inkább egy folytonos változóként kellene kezelni.

\section{A fogalmi váltás mint az ontológiai kategóriák közötti váltás: CHI, SLOTTA és DE LEEUW elmélete}

Az elmélet kiindulási pontja az, hogy az emberek különböző ontológiai kategóriákba sorolják a világ entitásait, és a kategóriának megfelelő jellemzőket tulajdonítják nekik. CHI és munkatársai három egymástól független, eltérő ontológiai jellemzőkkel rendelkező, hierarchikusan szerveződő kategóriát különítenek el: anyagok, folyamatok, mentális állapotok. Míg az egyes kategóriák ontológiai jellemzői kölcsönösen kizárják egymást, addig egy ontológiai kategórián belül lehetnek párhuzamos, azonos szinten levő kategóriák, amelyeket egy magasabb rendủ ontológiai jellemző összeköt.

A tévképzetek kialakulását ez az elmélet a hibás kategorizációval magyarázza. A gyerekeknél gyakran előfordul, hogy az egyes dolgokat nem a megfelelő kategóriába sorolják be, mert fóként az érzékelhető sajátságokra alapoznak. Például a kisgyerekek a bálnát halnak és nem emlősnek tekintik, mert vízben él és a halakhoz hasonlít. Különösen súlyosak azok az esetek, amikor a tanuló által választott és a tudomány által képviselt kategória ontológiailag eltérő. Például a fény, hő, elektromos áram, erő fogalmakat gyakran az „anyag” kategóriába sorolják a tanulók és anyagi jellemzőket tulajdonítanak nekik ahelyett, hogy „korlátozáson alapuló kölcsönhatási folyamatként” (constraint-based process), azaz egyensúlyi folyamatként értelmeznék. Ilyen „anyag alapú” tévképzet például az, hogy a tanulók az erőt gyakran a testtel közölt lendületnek tekintik, vagy a test által birtokolható és felhasználható sajátságnak. A tanulók biológiai tévképzetei között találtak „mentális alapú” tévképzeteket is, amikor egyes biológiai jelenségeket az állatok emocionális állapotai szerint interpretáltak a gyerekek a fiziológiai körülmények helyett. Ilyen 
például az, hogy az állatok növekedését (CAREY, 1985) vagy CHI és munkatársai (1994) vizsgálataiban a szívbillentyűk működését és a környezethez való alkalmazkodás evolúciós folyamatait az élőlény akaratának tulajdonították a tanulók.

Fogalmi váltás akkor történik, amikor egy fogalmat az egyén átsorol egy ontológiailag eltérő kategóriába. A fogalom ontológiai státusában történt váltást radikális fogalmi váltásként értelmezik. Arra a kérdésre azonban nem adtak konkrét választ, hogy egy ontológiai kategórián belüli párhuzamos kategóriái közötti váltást a fogalmi váltás alacsonyabb szintjeként lehet-e értelmezni.

CHI és munkatársai az ún. „összeférhetetlenségi hipotézis” alapján megpróbálták értelmezni azt a jelenséget, hogy bizonyos tévképzeteket a tanítás sem tud megszüntetni, sőt e fogalmak tanulása során még újabb tévképzetek is keletkezhetnek. Magyarázatuk szerint a fogalmak tanulási nehézsége attól függ, hogy a gyerekek naiv fogalmai és a nekik megfelelő tudományos fogalmak kompatíbilisek-e vagy sem. A kompatíbilis fogalmak esetében a naiv és a tudományos fogalmak ontológiai státusa azonos, azaz a gyerekek már az iskolai tanulmányok előtt a helyes ontológiai kategóriába sorolják az adott fogalmat. Az iskolai tanulmányok során csak a fogalom jelentésének finomítására és a fogalom ontológiai kategórián belüli helyének pontosabb kijelölésére van szükség. A kompatíbilis fogalmak (pl. élőlény, növény, állat, ember, emlős, hal, keringési rendszer) esetében tehát nincs szükség erőteljes fogalmi váltásra a mélyebb megértéshez. E fogalmak tanulása könnyebb, és a naiv fogalmak esetében jelentkező tévképzetek könnyebben korrigálhatók. Ezt alátámasztják CAREY (1985) eredményei is, amelyek szerint a gyerekek tévképzetei az élőlény, állat, növény, ember fogalommal kapcsolatban tízéves korra megszűnnek. Az állat fogalommal kapcsolatos kezdeti tévképzetek oka például az, hogy azt a gyerekek az ember fogalom változataként reprezentálják. Az állat és az ember kategória azonban a tanulás során könnyen a helyére kerül.

A kompatíbilis fogalmakkal ellentétben az inkompatíbilis fogalmak kezdeti ontológiai besorolása nem egyeztethető össze a tényleges ontológiai státusukkal. Az ilyen fogalmak (pl. erő, mozgás, hő, elektromos áram, diffúzió, evolúció) tanulása során fogalmi váltásra van szükség, azaz a fogalmat át kell tenni másik ontológiai kategóriába. Tehát az inkompatíbilis fogalmak, például az erővel kapcsolatos tévképzetek feltűnő stabilitásának oka az, hogy az erővel kapcsolatos előzetes fogalmat a tanulók az „anyag” kategória alatt tárolják, a „folyamat” kategória „korlátozáson alapuló kölcsönhatás" kategóriája helyett. Így a tanulás során az erővel kapcsolatos új információkat is az „anyag” ontológiai kategóriába építik be. A tanulók ezért soha nem tudják tökéletesen megérteni az erő fogalmát

A kompatíbilis és inkompatíbilis fogalmak megkülönböztetésével meg lehet magyarázni azt is, hogy CAREY (1985) miért tudta olyan nehezen összeegyeztetni adatait az általa kidolgozott fogalmi váltás elmélettel. Adatai ugyanis az állat fogalommal voltak kapcsolatosak és ez a fogalom kompatíbilis, tehát tanulása nem jelent különösebb nehézséget és nem igényel erős fogalmi váltást.

Az elmélet gyenge pontjait több kritikai észrevétel is kiemeli. VOSNIADOU és SCHNOTZ (1997) szerint ez az elmélet csupán szintaktikai (kategorizáció szintje) és nem szemantikai (elméleti szint: keret- és specifikuselmélet) magyarázata a fogalmi váltásnak. További feltevésekre van ugyanis szükség annak megértéséhez, hogy 
egy ontológiai kategórián belül egyes átszerveződések miért mennek könnyebben végbe, mint mások, illetve az ontológiai kategóriák közötti váltások miért nehezebbek, mint a kategórián belüliek. (Miért nehezebb a hő fogalmát áttenni az „anyag” kategóriából a „folyamat” kategóriába, és a miért nem olyan nehéz átsorolni a bálna fogalmát a „hal” kategóriából az „emlős” kategóriába?) DUIT és TREAGUST (1998) idézi Duit kritikáját, aki szerint a kategóriák egyrészt önkényesen választottak, másrészt túlságosan leegyszerűsítettek, és az esetek többségében a kategóriák közötti váltás nem megfelelő arra, hogy leírja az egyes fogalmak fejlődésének bonyolult folyamatait, például a hétköznapi életben használt differenciálatlan hő fogalom felbomlását a hőmérséklet, hőenergia, belső energia és entrópia fogalmakra.

\section{A fogalmi váltás mint a naiv keretelmélet feltevéseinek megváltoztatása: VOSNIADOU elmélete}

VOSNIADOU (1994b) egyetért azzal a korábban már ismertetett nézettel, hogy a fizikai világhoz füződő tudásunkat tartományspecifikus alapelvek határozzák meg. Ezeket a veleszületett, tartományspecifikus megszorításokat és a hétköznapi tapasztalatokon alapuló következtetések révén kialakult korlátozó elveket bemélyített előfeltevéseknek (entrenched presuppositions) nevezi. Ezek a feltevések a naiv fizika globális elméletét hozzák létre, amit tudatosan nem lehet elérni, és nem lehet hipotézisekkel tesztelni. E naiv fizika determinálja az ismeretszerzés folyamatát, hasonlóan a tudományos elméletek fejlődését meghatározó paradigmákhoz.

A tanulók intuitív tudásában két elméleti struktúra, a naiv keretelmélet és a specifikus elmélet különíthető el. A fizika naiv keretelméletét a bemélyített előfeltevések határozzák meg. Ezek egyrészt ontológiai előfeltevések (pl. „a fizikai objektumokra jellemző a szilárdság és az állandóság”; ,a szerveződés iránya felülről lefelé mutat”; „a gravitáció felülről lefelé hat”), másrészt episztemológiai előfeltevések (pl. „,a dolgok olyanok, amilyennek látszanak”). A specifikus elméletek tartományspecifikus, egymással összefüggő propozíciókból állnak, amelyek leírják egy fizikai objektum sajátságait és viselkedését. A specifikus elméletek megfigyelések, kulturális információk révén vagy pedig a keretelmélet megszorítása alatt prezentált információkon keresztül jönnek létre. Például a Földdel kapcsolatos megfigyelések: „a földfelszín ugyanazon sík mentén helyezkedik el nagy távolság esetén is”; „a földfelszín felett található az ég”; „a Föld alatt talaj és/vagy víz van”. Az alapvető tudásstruktúrák - keret- és specifikus elméletek - korlátozása alatt alakulnak ki a gyerekek elképzelései, meggyőződései a világról (pl. „a Föld lapos és mozdulatlan”; ,a Földet az alatta levő talaj vagy víz támasztja alá”; ,a Nap, Hold és a csillagok a Föld felett helyezkednek el”). E meggyőződések alapján jönnek létre a korábban már bemutatott mentális modellek a Földdel kapcsolatban.

Az ismeretszerzés folyamata lassú, fokozatosan halad az iniciális modellekből kiindulva tévképzeteken - VOSNIADOU (1994b) kifejezésével szintetikus modelleken - keresztül a tudományos modell felé. A fejlődés során a szintetikus modellek megjelenése attól függ, hogy mennyi mélyen beivódott nézetet változtattak meg a 
gyerekek. Azok a modellek, amelyek kevesebb változtatást igényelnek („,duális Föld” modell, „lyukas gömb” modell, „lapított gömb” modell), gyakrabban fordultak elő a fiatalabb gyerekeknél, míg a legnagyobb mértékű változtatást igénylő „bolygó” modell az idősebb (10-12 éves) gyerekeknél volt gyakoribb.

A Vosniadou által javasolt elméleti keretben a fogalmi váltásnak különböző fokozatait lehet értelmezni. A fogalmi váltás legkönnyebb formája az, amikor a meglevő tudásba beépül az új információ. Ez a gazdagodási folyamat különösebb nehézségektől mentes, mivel a régi információval összeegyeztethető az új. Ha viszont az új információ nem egyeztethető össze a meglevő feltevésekkel, meggyőződésekkel, akkor a régi tudás felülvizsgálatára van szükség. A specifikus elmélet felülvizsgálata sokkal könnyebb, mint a keretelméleté. Például a gyerekek könynyebben elfogadják, hogy a Holdon nincs víz és oxigén, mert a Holddal kapcsolatos specifikus elmélet a Földdel való analógián alapult, és nem egy naiv keretelmélet befolyásolta. Azt viszont nagyon nehezen értik meg, hogy a Föld gömb alakú, mert ez ellentmond a naiv keretelmélet hétköznapi tapasztalatokon alapuló feltevéseinek: „a tér fel és le irányok szerint szerveződik”, „a gravitáció felülről lefelé hat". A fogalmi váltás legnehezebb formája tehát a keretelmélet bemélyített feltevéseinek felülvizsgálatát követeli meg. Ekkor többféle tanulási nehézség jelentkezhet. Gyakran az új ismeretet a tanulók megtanulják, de nem értik. Ez a tudásfajta csak bizonyos esetekben, például iskolai rutinfeladatoknál mobilizálódik, problémaszituációkban viszont csak tehetetlen tudás. Van azonban olyan eset is, amikor a tanulók megpróbálják összehangolni az egymásnak ellentmondó tudáselemeket. E kognitív erőfeszítés eredményei a szintetikus modellek.

VOSNIADOU (1994b) rámutat arra, hogy McCloskey (1983) és CAREY (1985) nézetével szemben a tévképzetek spontán konstrukciók, amelyek gyakran a tesztelés során jönnek létre, a szituációtól függően változhatnak és nem mélyen bevésődött specifikus elméletek. Az oktatásnak, a változásnak nem maguk a tévképzetek állnak ellen, hanem az azokat meghatározó feltevések.

\section{A fogalmi váltás mint a fragmentált tudás koherenciájának növelése: DISESSA elmélete}

Ez az elmélet a fogalmi váltást komplex tudásrendszerek és azok evolúciójának megértésén keresztül vizsgálja, és a fogalmi váltás jelenséget az előzőekben ismertetett elméletekhez képest alapvetően másként közelíti meg. Azt hangsúlyozza, hogy a fizikai világgal kapcsolatos intuitív tudás izolált és fragmentált tudásdarabokból áll. A gyerekek gazdag intuitív tudásának számos eleme és kombinációja van. A tanulók egy témán belül lehetnek konzisztensek, de a fizikai jelenségek különböző kontextusaiban eltérő módon gondolkodnak. A gyerekek számos részleges modellel rendelkeznek, amit különböző helyzetekben használnak, de nincs modelljük például az erő és a mozgás kapcsolatára. Az izolált tudásdarabok primitív sémák, fenomenológiai alapelvek (p-prims), amelyek csak felületes interpretációi a valóságnak. A fizikai jelenségek magyarázatában viszont fontos szerepet töltenek be, és segítik a tévképzetek létrejöttét. Például a lendületelmélet olyan 
fenomenológiai alapelvekhez kapcsolódik, mint „az erő egy mozgató”, ,az elhalás vagy elhalkulás”, vagy a „dinamikus egyensúly”. Ezek az alapelvek leírnak egy bizonyos szituációt, de nem hoznak létre koherens, szisztematikus elméletet.

A fogalmi váltás a több száz, esetleg több ezer fenomenológiai alapelv újraszerveződését jelenti, aminek eredményeként nő a tudás koherenciája, konzisztenciája. A fogalmi váltás legfontosabb típusa a fenomenológai alapelvek funkciójában bekövetkezett váltás, amely során megszűnik azok önmagyarázó jellege, és olyan komplexebb tudásstruktúrákhoz kötődnek, mint a fizikai törvények vagy alapelvek. Az újoncok és a szakértők közötti különbség tehát az, hogy az újoncok tudása szétdarabolt, míg a szakértőké törvényekhez és alapelvekhez kötött.

\section{A fogalmi váltás kognitív fejlődéslélektani elméleteivel kapcsolatos birálatok}

Az elméleti pontatlanságokra több kutató is felhívta a figyelmet. DISESSA és SHERIN (1999) kritikai elemzésükben rámutatnak arra, hogy a legtöbb elmélet nem definiálja precízen központi fogalmait (fogalmak, elméletek, ontológiák); a leírások túl durvák, nem írják le pontosan azt a hosszú és komplex utat, amelyet a tanulók megtesznek, amikor „A” fogalomból „B”-be jutnak; nem veszik figyelembe az egyéni különbségeket. Kritikájukban különösen CAREY (1986) elméletét mint a fogalmi váltás „standard elméletét” vitatják. Szerintük ez tipikus példája azoknak a pedagógiai megközelítéseknek, amelyek a fogalmi váltást a fogalmak változásának tekintik anélkül, hogy definiálnák azt, mit is értenek fogalom alatt. DISESSA és munkatársa a különböző minőségű fogalmakra más-más elméleti konstrukciók kidolgozását tartja fontosnak. A hagyományos, fóként a kategóriafogalmakra korlátozódó fogalomelmélettel szemben kidolgozták a koordinációs osztályok (coordination classes) elméletét a fogalmak egy csoportjának modellezésére. A koordinációs osztályok a tudás nagy, integrált rendszerei, amelyeket a tudományos fogalmakhoz lehet hasonlítani. Mindazon eljárások komplex készletét értik alattuk, amelyeket az emberek arra használnak, hogy a külvilággal kapcsolatos információk bizonyos csoportját megszerezzék, kiolvassák.

CARAVITA és Halldén (1994), illetve White (1994) szintén a klasszikus fogalomértelmezés korlátaira mutatnak rá, amikor arra hívják fel a figyelmet, hogy a fogalmi váltást túlzott leegyszerüsítés a kategorizáció megtanulásának, illetve a fogalomhoz kapcsolt ismeretek bővülésének tekinteni. Gyakran a magyarázó rendszerekben, koncepciókban történik változás, ezért fontosnak tartják a koncepcionális váltások vizsgálatát is.

CHI és munkatársai (1994) az elméleti problémák közül azt a zavaró jelenséget említik, hogy a fogalmi váltás kifejezés egyaránt használatos a váltás folyamatára és a váltás eredményére is. Bár nagyon sokféle értelmezése van a fogalmi váltásnak, még napjainkban is nyitott kérdés az, mi változik valójában a fogalmi váltás során; mi jellemzi az egyes fogalmi váltás típusokat; milyen esetekben van szükség radikális átszervezésre; mi történik a megváltozott tudáselemekkel; melyek azok a tartományspecifikus jellemzők, amelyek hatással vannak a fogalmi váltás folyamatára.

Napjainkban erősen széttagolódott a fogalmi váltás kutatása, mivel az egyes 
kutatók nagyrészt a különböző tantárgyi területek egyes témái, fogalmai esetében bekövetkezett változásokra koncentrálnak. Ez a tendencia nem segíti elő azt, hogy az ismeretszerzés folyamatának általános kérdéseire válasz szülessen. A tartományspecifikus vizsgálatok által felhalmozott adatokat áttekintve választ kell a jövőben adni arra a kérdésre, hogy vannak-e olyan általános folyamatok, amelyek mindegyik területen megjelennek, és ezeket milyen tényezők befolyásolják.

\section{A FOGALMI VÁLTÁS KUTATÁSÁNAK MÁS IRÁNYAI}

Az eddigiekben a fogalmi váltás folyamatával kapcsolatos kutatásokat alapvetően két megközelítésben, a természettudományok tanítása, illetve a kognitív fejlődéslélektani kutatások alapján mutattuk be. A két irány kiindulási alapja közös. Mindkettő összeegyeztethetetlennek tartja a régi és az új tudást, a gyerekek intuitív elméleteit és a tudományos elméleteket. A természettudományok tanításával kapcsolatos kutatásokban domináló, POSNER és munkatársai (1982) által kidolgozott elmélet a régi fogalmak tudományosakra való kicserélését hangsúlyozza. A fogalmi váltás kognitív elméletei a fogalmi átszerveződés szélesebb skáláját értelmezik. A kognitív megközelítések SPADA (1994) szerint, bár nem a meglevő fogalmak lecserélését hirdetik, implicit módon mégis a régi meggyőződések háttérbe szorulását sugallják.

\section{A régi és az új ismeret kapcsolatának problémája}

A meglevő és tudományos ismeret viszonyának, illetve az ismeretelsajátítás folyamatának számos egyéb lehetősége is felmerült az utóbbi években (PozO, 1997; CHInN, BREwer, 1998). POzo (1997) áttekintésében az egyik elgondolás az, hogy a gyerekek elméletei és a tudományos elméletek összeegyeztethetők, mert ugyanazon kognitív folyamat eredményei. A tanulók agya formattálva van a tudomány elsajátítására (Karmiloff-Smith kifejezése), a tanulóknak csupán bővíteni és finomítani kell ismereteiket ahhoz, hogy az agyukban futó programok segítségével újraírják elméleteiket. A hagyományos iskolai gyakorlat ezt az utat követi. A gyerekeknek adott egyre több és bonyolultabb információtól azt várja, hogy az törvényszerủen elvezeti a diákokat a tudományos ismeretek megértéséhez.

A gyerekek intuitív elméletei és a tudományos elméletek együttélése mellett érvel SPADA (1994), illetve DuIT és TREaGust (1998). Nem vitatják azt, hogy bizonyos esetekben helyesebb elhagyni a további megértést nehezítő kezdeti meggyőződéseket. Vannak azonban olyan helyzetek, amikor jól hasznosíthatók bizonyos naiv elképzelések vagy problémamegoldó stratégiák is. SPADA (1994) ezért új oktatási célként a többszörös mentális reprezentációk létrehozásának elősegítését jelöli meg. A diákoknak meg kell tanulniuk annak felismerését, hogy különböző reprezentációk vannak egy adott dologgal, jelenséggel kapcsolatban. Látniuk kell azok korlátait, és tudniuk kell azt is, hogy az adott kontextusban mely reprezentáció használható sikeresen. 
Pozo (1997) szerint optimális esetben a tanulók az ismereteiket, elméleteiket hierarchikus rendszerbe építik. A saját kezdeti elméleteiket nem cserélik le, nem szorítják háttérbe, hanem az adott jelenség alacsonyabb elemzési szintjeként tekintik. Az ismereteknek ilyen megkülönböztetése és egymásba építése azonban nagyfokú metakognitív tudatosságot igényel a tanulóktól.

\section{A kontextus, a szituáció, a motiváció hatása a fogalmi váltásra}

Az 1980-as években és az 1990-es évek elején a pedagógia tanulásfelfogására erőteljes hatást gyakorolt a konstruktivizmus ún. individuális konstruktivista iránya (Duit, Treagust, 1998; Dusch, Hamilton, 1998). Ez az irányzat a tudás egyéni konstruálását hangsúlyozta. A tanuló egyénileg hozza létre tudását a már meglevő tudásbázisa alapján, és a külvilágról alkotott modellek az egyén elméjében tárolódnak. A tanulás lényege az egyéni mentális modellek létrehozása. Ez az irányzat főként az egyéni elméletekben megjelenő kvalitatív különbségekre koncentrál, és azt vizsgálja, hogyan változnak meg e különbségek a tanulás hatására.

Napjainkban az individuális konstruktivista irányt egyre több kritika éri amiatt, hogy az túlhangsúlyozza az egyéni tanulást a tudáskonstrukció folyamatában, és nem veszi figyelembe a szociális faktorokat. Az 1990-es évek elejétől a konstruktivizmus egy másik iránya, a szociális konstruktivizmus is megjelent a pedagógiai kutatásokban. Ez az irányzat Vigotszkij nézeteit eleveníti fel és azt hangsúlyozza, hogy a tanulásban a társas folyamatoknak is nagy szerepe van. A tudás elsősorban nem egyéni termék, hanem az egyén és a közösség kölcsönhatásának eredménye. A tudás megoszlik egy adott közösség tagjai között.

A szociális konstruktivizmus hatásának tudható be az, hogy a fogalmi váltás kutatásokban is egyre gyakrabban merül fel az a gondolat, hogy nem kizárólag a kognitív tényezőket kell elemezni, hanem figyelembe kell venni a fogalmi váltást befolyásoló motivációs és osztálytermi hatásokat (PINTRICH, MARX, BOYLE, 1993; PINTRICH, 1998).

A tanulással kapcsolatos jelenlegi pszichológiai kutatások hatására a fogalmi váltás területén is megjelent a szituáció és a kontextus szerepének hangsúlyozása (Caravita, Halldén, 1994; Schoultz, Saljö, Wyndhamn, 1997). A fogalmi váltást segítő, metakognitív tanulási környezetek tervezésében is a szituációhoz, kontextushoz kötöttség, illetve a szociálisan közvetített tanulás jelenik meg. A társakkal való együttműködést, az egyéni nézetek megvitatását, a tanulók és tanárok episztemológiai meggyőződéseinek felszínre hozását célozzák meg a jelenleg kidolgozás alatt álló tanítási stratégiák (MASON, 1998).

A fogalmi váltással kapcsolatos irodalom rendkívül gazdag és szerteágazó. A különböző megközelítések a jelenség más-más aspektusát emelik ki. A felmerülő újabb irányok a kérdések sokaságát indítják el. A fogalmi váltás folyamatának általános leírásához, a továbblépéshez ki kell építeni a hidat a természettudományok tanításával foglalkozó kutatások és a kognitív fejlődés folyamatának vizsgálata között. Olyan tanuláselmélet kifejlesztése a cél, amely meghatározza a változás mechanizmusait, és azokat hozzákapcsolja a szituációs, kontextuális, motivációs és 
kulturális változókhoz (VOSNIADOU, 1998). A fogalmi váltás folyamatának pontosabb megértése továbbra is fontos feladat. Nemcsak azért, hogy megértsük, hogyan tanulnak a diákok, hanem azért is, hogy hatékonyabb tanulási feltételeket teremtve könnyebbé és hatékonyabbá lehessen tenni a tanulásukat.

\section{IRODALOM}

Anderson, C. W., Smith, E. L. (1987) Teaching science. In Richardson-Koehler, V. (ed.) Educators' handbook: A research perspective. 84-111. Longman, New York

Ausubel, D. P. (1968) Educational psychology: A cognitive view. Holt, Rinehart and Winston, New York

Bliss, J., Ogborn, J. (1994) Force and motion from the beginning. Learning and Instruction, 4, 7-25.

BRnA, P. (1988) Confronting misconceptions in the domain of simple electrical circuits. Instructional Science, 17, 29-55.

Caramazza, A., McCloskey, M., Green, B. (1981) Naiv beliefs in "sophisticated" subjects: misconceptions about trajectories of objects. Cognition, 9, 117-123.

CARAvita, S., Halldén, O. (1994) Re-framing the problem of conceptual change. Learning and Instruction, 4, 89-111.

CAREY, S. (1985) Conceptual change in childhood. MIT Press, Cambridge

Carey, S. (1986) Cognitive science and science education. American Psychologist, 41, 11231130.

Carey, S. (1995) On the origin of causal understanding. In Sperber, D., Premack, D., Premack, A. J. (eds) Causal cognition: A multidisciplinary debate. 268-302. Oxford University Press, Oxford

Carey, S., Spelke, E. S. (1994) Domain specific knowledge and conceptual change. In Hirschfeld, L. A., Gelman, A. (eds) Mapping the mind: Domain specificity in cognition and culture. 169-200. Cambridge University Press, Cambridge

Champagne, A. B., Gunstone, R. F., Klopfer, L. E. (1985) Instructional consequences of students' knowledge about physical phenomena. In West, L. H. T., Pines, A. L. (eds) Cognitive structure and conceptual change. 61-91. Academic Press, Orlando

Chi, M. T. H., Slotta, J. D., DE Leeuw, N. (1994) From things to processes: a theory of conceptual change for learning science concepts. Learning and Instruction, 4, 27-43.

Chi, M. T. H., Glaser, R., Rees, R. (1982) Expertise in problem solving. In Sternberg, R. J. (ed.) Advances in the psychology of human intelligence. 7-76. Lawrence Erlbaum Associates Inc., Hillsdale

Chinn, A. Clark, Brewer, W. F. (1998) Theories of knowledge acquisition. In Fraser, B. J., Tobin, K. G. (eds) International Handbook of Science Education. 97-113. Kluwer Academic Publishers, Boston

Clement, J. (1982) Students' preconceptions in introductory mechanics. American Journal of Physics, 50, 66-71.

Clement, J. (1993) Using bridging analogies and anchoring intuitions to deal with students' preconceptions in physics. Journal of Research in Science Teaching, 10, 1241-1257. 
Cosmides, L., Tooby, J. (1994) Origins of domain specificity: The evolution of functional organization. In Hirschfeld, L. A., Gelman, A. (eds) Mapping the mind: Domain specificity in cognition and culture. 85-116. Cambridge University Press, Cambridge

Diakidoy, I., Vosniadou, S., Hawks, J. D. (1997) Conceptual change in astronomy: Models of the earth and of the day/night cycle in american-indian children. European Journal of Psychology of Education, 2, 159-183.

DISESSA, A. (1993) Towards an epistemology of physics. Cognition and Instruction, 10, 105225.

DiSessa, A. (1998) Theoretical problems about conceptual change. Paper presented in the session „Theoretical problems about conceptual change”. Second European Symposium on Conceptual Change. Universidad Autónoma de Madrid, November 6-8.

DISESSA, A., SHERIN, B. L. (1999) What changes in conceptual change? International Journal of Science Education (megjelenés alatt)

Duit, R., Treagust, D. F. (1998) Learning in science - From behaviorism towards social constructivism and beyond. In Fraser, B. J., Tobin, K. G. (eds) International Handbook of Science Education. 3-27. Kluwer Academic Publishers, Boston

Dusch R. A., Hamilton, R. J. (1998) Conceptual change in science and in the learning of science. In Fraser, B. J., Tobin, K. G. (eds) International Handbook of Science Education. 1047-1065. Kluwer Academic Publishers, Boston

ErICKSON, G. L. (1979) Children's conceptions of heat and temperature. Science Education, 63, 221-230.

Finegold, M., Gorsky, P. (1988) Learning about forces: simulating the outcomes of pupils' misconceptions. Instructional Science, 17, 251-261.

GilberT, J. K., WATTS, D. M. (1983) Concepts, misconceptions and alternative conceptions: Changing perspectives in science education. Studies in Science Education, 10, 61-98.

Gilbert, J. K., Osborne, R. J., Fensham, P. J. (1982) Children's science and its consequences for teaching. Science Education, 4, 623-633.

Gunstone, R. F., White, R. T. (1981) Understanding of gravity. Science Education, 65, 291-299.

Hartnett, P., Gelman, R. (1998) Early understandings of numbers: Paths or barriers to the construction of new understandings? Learning and Instruction, 4, 341-374.

Hatano, G., INAGAKI, K. (1997) Qualitative changes in intuitive biology. Journal of Psychology of Education, 2, 111-130.

Hewson, P. W. (1981) A conceptual change approach to learning science. European Journal of Science Education, 3, 383-396.

Hewson, P. W., Hewson, M. G. (1984) The role of conceptual conflict in conceptual change and the design of science education. Instructional Science, 13, 1-13.

Hewson, P. W., Beeth, M. E., Thorley, N. R. (1998) Teaching for conceptual change. In Fraser, B. J., Tobin, K. G. (eds) International Handbook of Science Education. 199-218. Kluwer Academic Publishers, Boston

INAGAKI, K. (1997) Emerging distinctions between naive biology and naive psychology. In Wellman, H. M., Inagaki, K. (eds) The emergence of core domains of thought: Children's reasoning about physical, psychological and biological phenomena. 27-44. Jossey-Bass Publishers, San Francisco

Inhelder, B., Piaget, J. (1967) A gyermek logikájától az ifjú logikájáig. Akadémiai Kiadó, Budapest 
KEIL, F. C. (1994) The birth and nurturance of concepts by domain: The origins of concepts of living things. In Hirschfeld, L. A., Gelman, A. (eds) Mapping the mind: Domain specificity in cognition and culture. 234-254. Cambridge University Press, Cambridge

Korom E. (1997) Naiv elméletek és tévképzetek a természettudományos fogalmak tanulásában. Magyar Pedagógia, 1, 19-40.

Kuhn, K., Aguirre, J. (1987) A case study - on the 'journal method' - a method designed to enable the implementation of constuctivist teaching in the classroom. In Novak, J. D. (ed.) Proceedings of the second international seminar on misconceptions and educational strategies in science and mathematics. 262-274. Cornell University, Ithaca

Kunn, T. S. (1984) A tudományos forradalmak szerkezete. Gondolat Könyvkiadó, Budapest

Lakatos, I. (1968) Criticism and the Methodology of Scientific Research Programs. Proceedings of the Aristotelian Society 69. London (Magyarul: LAKATOS Imre (1997) A kritika és a tudományos kutatási programok metodológiája. In Miklós T. (szerk.) Lakatos Imre tudományfilozófiai írásai. 19-63. Atlantisz Könyvkiadó, Budapest)

Lehtinen, E., Merenluoto, K., Kasanen, E. (1997) Conceptual change in mathematics: From rational to un(real) numbers. European Journal of Psychology of Education, 2, 131147.

Limón, M., Carretero, M. (1997) Conceptual change and anomalous data: A case study in the domain of the natural sciences. European Journal of Psychology of Education, 2, 213230.

Markham, K. M., Mintzes, J. J., Jones, M. G. (1994) The concept map as a research and evaluation tool: Further evidence of validity. Journal of Research in Science Teaching, 1, 91-101.

MASON, L. (1998) Instructional strategies to promote conceptual change. Paper presented in the session "Instruction and conceptual change" session. Second European Symposium on Conceptual Change. Universidad Autónoma de Madrid, November 6-8.

McCloskey, M. (1983) Naive theories of motion. In Genter, D., Stevens, A. (eds) Mental models. Erlbaum, Hillsdale

MÉRŐ L. (1994) Észjárások. A racionális gondolkodás korlátai és a mesterséges intelligencia. Akadémiai Kiadó-Optimum, Typotex

Novak, J. D. (1990) Concept mapping: A useful tool for science education. Journal of Research in Science Teaching, 10, 937-949.

Novick, S., Nussbaum, J. (1981) Pupils' understanding of the particulate nature of matter: A cross-age study. Science Education, 65, 187-196.

Nussbaum, J. (1979) Children's conception of Earth as a cosmic body: A cross-age study. Science Education, 63, 83-93.

Nussbaum, J. (1989) Classroom conceptual change: Philosophical perspectives. International Journal of Science Education, 11, 530-540.

Nussbaum, J., Novick, S. (1982) Alternative frameworks, conceptual conflict and accommodation: Toward a principled teaching strategy. Instructional Science, 11, 183-200.

Pfundt, H., Duit, R. (1991) Bibliography: Students' alternative frameworks and science education. (Harmadik kiadás) Institute for Science Education at the University of Kiel, Kiel

Piaget, J. (1929) The child's conceptions of the world. Harcourt, Brace and Company, New York

PiageT, J. (1970) Válogatott tanulmányok. Gondolat Kiadó, Budapest 
PINTRICH, P. R. (1998) The role of classroom contextual features and motivational beliefs in conceptual change. Paper presented in the session „Social, contextual and motivational aspects of conceptual change" Second European Symposium on Conceptual Change. Universidad Autónoma de Madrid, November 6-8.

Pintrich, P. R., Marx, R. W., Boyle, R. A. (1993) Beyond cold conceptual change: The role of motivational beliefs and classroom contextual factors in the process of conceptual change. Review of Educational Research, 6, 167-199.

PolÁnyi, M. (1958) Personal Knowledge. University of Chicago, Chicago (Magyarul: PolánYi Mihály (1994) Személyes tudás. Atlantisz Könyvkiadó, Budapest)

Posner, G. J., Strike, K. A., Hewson, P. W., Gertzog, W. A. (1982) Accommodation of a scientific conception: Toward a theory of conceptual change. Science Education, 66, $211-$ 227.

Pozo, J. I. (1997) A fogalmi váltás: Az újraszerkesztés, kifejtés és hierarchikus beépülés folyamata. Iskolakultúra, 12, 47-57.

RoTH, K. (1990) Developing meaningful conceptual understanding in science. In Jones, B., Idol, L. (eds) Dimensions of thinking and cognitive instruction. 139-175. Erlbaum, Hillsdale

Schoultz, J., SAljö, R. Wyndhamn, J. (1997) Heavenly talk: A discursive approach to conceptual knowledge and conceptual change in children's understanding of elementary astronomy. Paper presented in the symposium „The relationships between conceptual change and learning" 7th European Conference for Research on Learning and Instruction. Athens, Greece, August. 26-30.

SPADA, H. (1994) Conceptual change or multiple representations? Learning and Instruction, 4, 113-116.

StePans, J. (1996) Targeting students' science misconceptions: Physical science concepts using the conceptual change model. Idea Factory, Inc. Riverview

Strike, K. A., Posner, G. J. (1982) Conceptual change and science teaching. European Journal of Science Education, 4, 231-240.

Strike, K. A., Posner, G. J. (1985) A conceptual change view of learning and understanding. In West, L. H. T., Pines, A. L. (eds) Cognitive structure and conceptual change. 189-211. Academic Press, Orlando

Tiberghien, A. (1994) Modeling as a basis for analyzing teaching - Learning situations. Learning and Instruction, 4, 71-87.

VASS V. (1997) Történelmi tévképzetek a tanulók gondolkodásában. Iskolakultúra, 10, 99-105.

VOSNIADOU, S. (1994a) Universal and culture-specific properties of children's mental models of the earth. In Hirschfeld, L. A., Gelman, A. (eds) Mapping the mind: Domain specificity in cognition and culture. 412-430. Cambridge University Press, Cambridge

Vosniadou, S. (1994b) Capturing and modeling the process of conceptual change. Learning and Instruction, 4, 45-69.

Vosniadou, S. (1998) Conceptual change: Theoretical problems and implications for science education. Paper presented in the session „Theoretical problems about conceptual change". Second European Symposium on Conceptual Change. Universidad Autónoma de Madrid, November 6-8.

Vosniadou, S., Brewer, W. F. (1990) A cross-cultural investigation of children's conceptions about the earth, the sun, and the moon: Greek and american data. In Mandl, H., De Corte, E. Bennett, N., Friedrich, H. F. (eds) Learning and instruction: European research in an international context. Vol. 2.2. 605-629. Pergamon Press, Oxford 
Vosniadou, S., Schnotz, W. (1997) Introduction. European Journal of Psychology of Education. Vosniadou, S., Schnotz, W. (eds) Special Issue: Advances in conceptual change Research. 2. 107-110.

Voss, J. F., Wiley, J. (1997) Conceptual understanding in history. European Journal of Psychology of Education, 2, 147-159.

WANDERSEE, J. (1985) Can the history of science help science educators anticipate students' misconceptions? Journal of Research in Science Teaching, 7, 581-597.

Watts, M., Bentley, D. (1987) Constructivism in the classroom: enabling conceptual change by words and deeds. British Educational Research Journal, 2, 121-134.

\title{
THEORIES OF CONCEPTUAL CHANGE
}

\author{
KOROM, ERZSÉBET
}

One of the intriguing meeting points of educational and psychological research is the area known in the literature as 'conceptual change', which emerged in the early 1980s and has studied the processes of concept learning and knowledge acquisition. In this research area the practice of education is intertwined with cognitive developmental psychological approaches and research especially on science education. Behind both directions lies the assumption that learning is an active process in which students interpret new information and construct their knowledge on the basis of their prior knowledge. That branch of conceptual change research which is closely linked to education sees the learning process as a conceptual change during which students' existing concepts should be substituted with scientific ones. Conceptual change research rooted in cognitive developmental psychology, however, studies the interactions between old and new knowledge, the changes in the conceptual system and tries to find ways to facilitate students' understanding of scientific information. The aims of the paper are (1) to survey the most significant tendencies of conceptual change research of the last two decades; (2) to present the most important empirical works and theories built upon them; (3) to highlight the yet unanswered questions; (4) to indicate the possible future directions in conceptual change research. The results of this research area yield a great deal of information for the understanding of students' conceptual development and call attention to certain educational consequences: e.g. much more attention should be paid to students' prior knowledge, beliefs and naive theories in the course of instruction, as well as to conscious concept teaching and learning.

Key words: knowledge acquisition, concept learning, conceptual change, misconception, concept teaching, science education, cognitive developmental psychology 